\title{
DESIGN OF A SIMPLE UPRIGHT COMPOST TURNING MACHINE FOR SMALL FARMER
}

\author{
Abdel - Mottaleb A.,F. *
}

ABSTRACT

The aim of this study is to design and construct a simple upright compost turning machine suitable for small Egyptian farms .The performance of the designed machine was investigated as a function $o$ f forward speed ( $0.3,0.6,0.8$ and $1.1 \mathrm{~m} / \mathrm{sec})$, rotor speed $(240,350$, and $460 \mathrm{rpm}$ ), number of compost turnings (1,2,3 and 4 times per month and pile shape (long pile and round pile). Machine capacity, fuel consumption, power, energy and turning cost were determined .

The main results in this study can be summarized in the following points:

- The composting time decreased from 24 weeks by manual method to 14 weeks by the new designed turning machine.

- The designed turning machine improves physical and chemical characteristics of the final compost comparing with the manual turning method.

It is recommended to use the designed turning machine for small farmer projects under the following conditions : forward speed of about 0.3 $\mathrm{m} / \mathrm{sec}$, for turning round - shape piles, $0.8 \mathrm{~m} / \mathrm{sec}$ for turning long shape piles, rotor speed of about $460 \mathrm{rpm}$ for both the two shapes of piles and 4 turnings per month .

\section{INTRODUCTION}

$\mathrm{F}$ Vield crop residues are considered one of the critical problems, which face the Egyptian farmer especially after harvesting. In Egypt, there are about 25 million tons yearly of the field raw material, the most important of which are rice straw (4million tons ), corn stalks ( 3.5 million tons ) and cotton stalks ( 2 million tons ).Ministry of Agr.( 2001 )

Therefore, the use of rice straw and other crop residues for making suitable and safe compost will reduce air pollution by avoiding field burning, reduce irrigation water by increasing water holding capacity, reduce mineral fertilizer consumption and finally help in producing safe healthy food.

* Senior Res ., Ag. Eng. Res. Inst . ( AEn.RI), Egypt . 
The good composting operation depends on the correct mixing and turning of materials. The compost turning and mixing in Egypt are still carried out manually, which is tedious and consumes long time with low production, Developed technologies such as front loader, tractor pulled and self propelled turning machine require high cost .

Rynk et al. (1992) stated that windrow composting consists of placing the mixture of raw materials in long narrow piles or windrows which are agitated or turned on a regular basis . Typically, the windrows, are initially from $0.9 \mathrm{~m}$ high for dense material like manures to $3.6 \mathrm{~m}$ high for fluffy materials like leaves. The width varies from 3 to $6 \mathrm{~m}$. The equipment used for turning determines the size, shape, and spacing of windrow . They also added that a number of specialized machines have been developed for turning windrows . this machines greatly reduce the time and labor involved, mix the materials thoroughly and produce amore uniform compost . some of these machines are designed to attach to farm tractor or front - end loader, others are self - propelled .

Barington et al , ( 1997 ) investigated mixing and aeration performance during composting of apple residues mixed with saw dust . They reported that temperature of 60 to $65 \mathrm{C}^{\circ}$ could be reached with initial $\mathrm{C} / \mathrm{N}$ ratio of 20 to 25 .

Yousef ( 2001 ) tested the feasibility of using fodder beet chopper as a dual purpose machine for turning and mixing the compost under local conditions comparing with the use of loader and manual methods. He concluded that the optimum conditions were peripheral speed of chopper between 4.54 and $5.34 \mathrm{~m} / \mathrm{s}$, cutting lengths of stalks less than $50 \mathrm{~mm}$ and compost moisture content less than $37.6 \%$ for turning and mixing compost.

Abd El - Motalleb and Kotob ( 2004 ) stated that the most critical factors selecting the agitating system were the cost requirements and the economic returns from the operation. The tractor pulled agitating machine requires minimum value of cost estimated at about ( 76.7 L. E./ton ) followed by the self propelled agitating ( 80.2 L.E./ton ). The economic returns were estimated at about $18.6 \%, 25 \%$ and $162 \%$ for the 
self propelled agitating front loader and the tractor pulled agitating respectively.

Abd El-Mottaleb ( 2006 ) recommended to use self propelled turning machine for large projects and the tractor side - mounted machine for medium and small projects, under the following conditions :-

- Forward speed about $0.2 \mathrm{~m} / \mathrm{sec}$. For both side mounted and self propelled turning machine-rotor speed of about $240 \mathrm{rpm}$.

- Number of compost turnings per month under all conditions was four times .

The objectives of this research are to :

- Design and construct of a simple upright compost turning machine suitable for small Egyptian farms .

- Optimize some different operating parameters affecting the manufactured machine performance .

- Compare the manufactured compost turning machine with the manual method with reference to final product quality .

\section{MATERIAL AND METHODS}

Field experiments were carried out through years of 2006 and 2007 in the Organization of land reform , Sharkia Governorate, to design , construct and evaluate a simple compost turning machine at appropriate for small Egyptian farmer :

\section{Materials :-}

\section{Row material used :-}

The materials used for composting were rice straw mixing with live stock manure to accelerate Composting process .

\section{The constructed compost turning machine :}

A simple compost turning machine, suitable for small Egyptian farms, is constructed at low cost from local materials, to overcome the problems of high power and high cost requirements under the use of imported machines .

Several points were taken into consideration in the development of the new turning machine as follows :

- The manufactured machine should work with small compost piles and with different pile shapes . 
- The manufactured machine is capable of reducing its width during transportation from one field to another.

- All moving shafts and gears are covered to achieve high degree of safety during work .

The compost turning machine design consists mainly of a frame , distribution unit, turning screws and transmission system as shown in figs : 1, 2, 3, 4 and photograph : ( 5, 6 and 7 ).

\section{The frame :-}

The frame is made of good grade channel-section steel ( U ) of thickness $(50 \mathrm{~mm})$ and dimensions of ( 500-800 $\mathrm{mm}$ ). The frame comprises four rectangular component .

The first one is horizontal and the other three were fixed together in a trapezoidal shape. The horizontal one is used for fixing transmission system group, reducer, attaching to tractor and direction turntable. The other there rectangles contain turner tunnel with cater corner shape in horizontal position by the same size fixing of loading bearing for flexable joint, transmission system and gearbox .

\section{Machine direction :-}

Machine direction is divided into two positions: Tractor rear-mounting during moving at the road and side position for operation .

\section{Distributing unit}

Distribution unite is used for distributing both water and macro organization solution .It consists of stop cock nozzle and distribution lines are mounted at the top level for turner. There is a top tank divided from inside into - two parts the first part for providing with necessary water for pile humidity during turning, and the other part for spraying the solution during turning process .Every part connected with hollow pipe at the level of machine for water or solution outgoing and stopcock to control spray rate. 


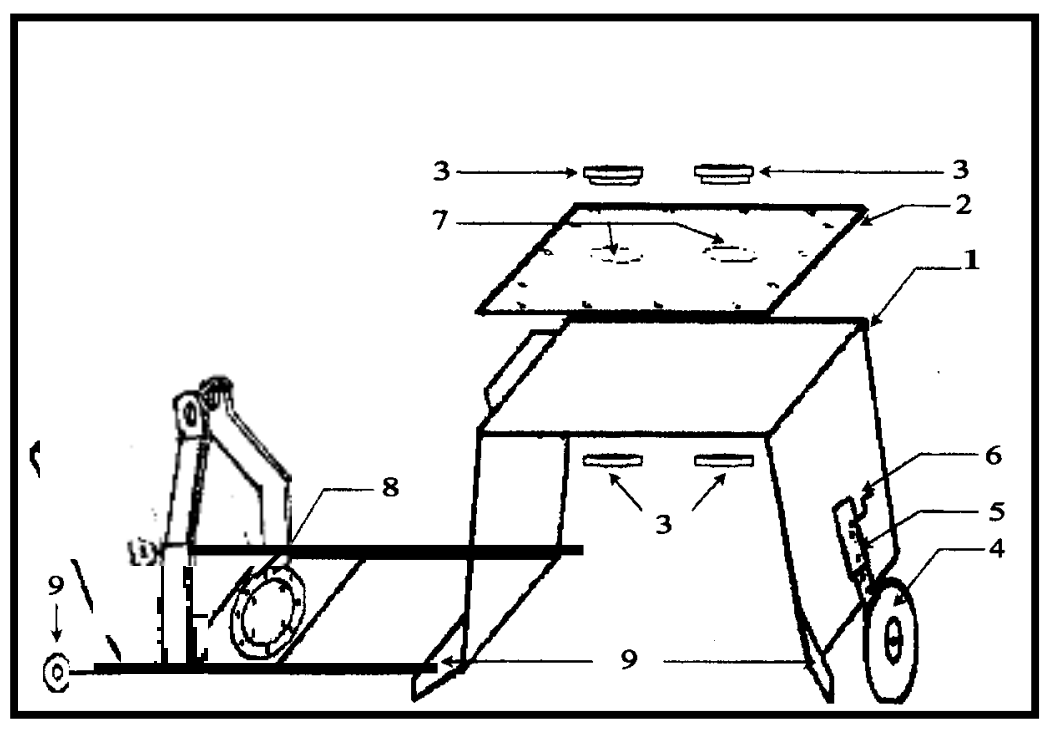

Fig. 1: Elvation view compose upright turning machine

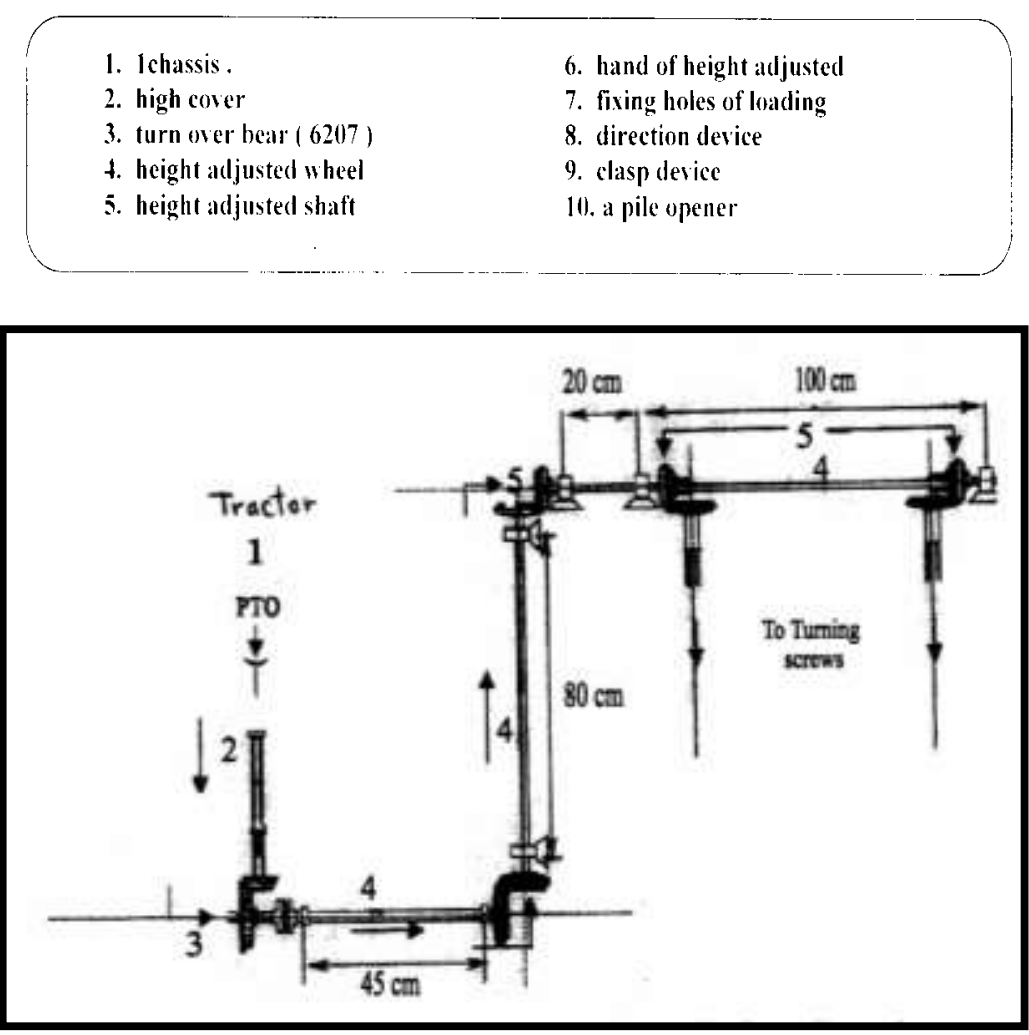

Fig. 2: diagram of transmission system in compost upright turning machine
1. PTO
2. flexable jeint
3. reducer
4. connecting shafts
5. transmission bevd gears groups
6. fimbriate shaft to connect the movement to taraing serews 


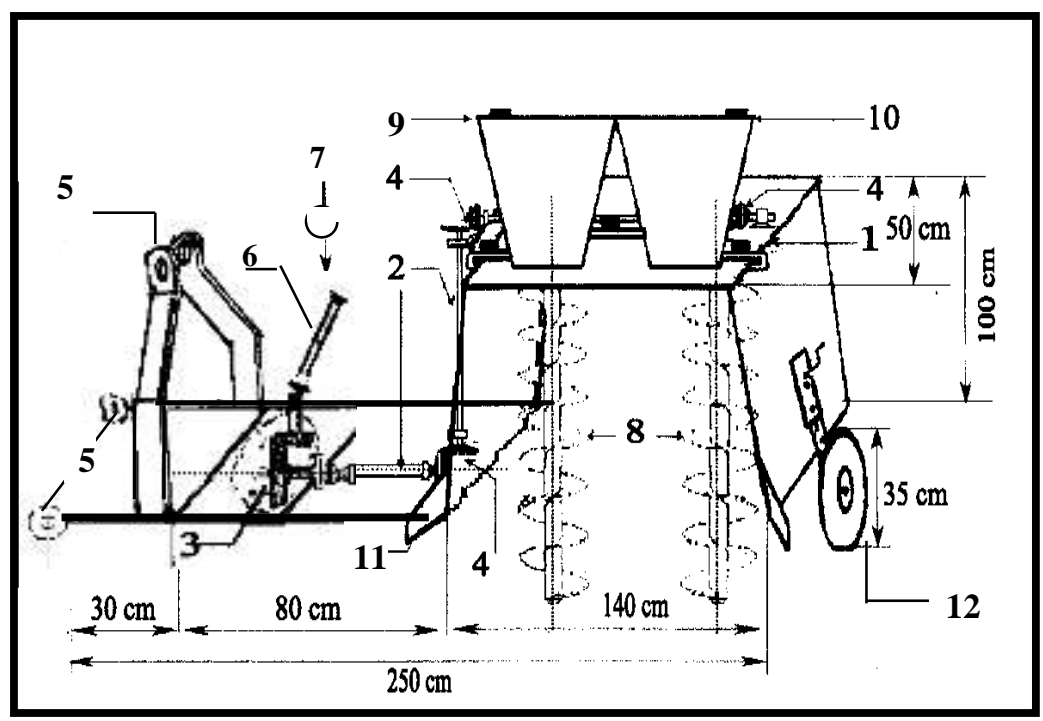

Fig. 3: Oblique sketch of compost upright turning machine

1. Chassis.

2. Connecting shaft.

3. Reducer.

4. Bevel gear.

5. Hitch points, Category II.

6. Flexible Joint .
7. PTO .

8. Screw .

9. Microbial tank .

10. Water tank

11. Apile opener

12. Height adjusted wheel

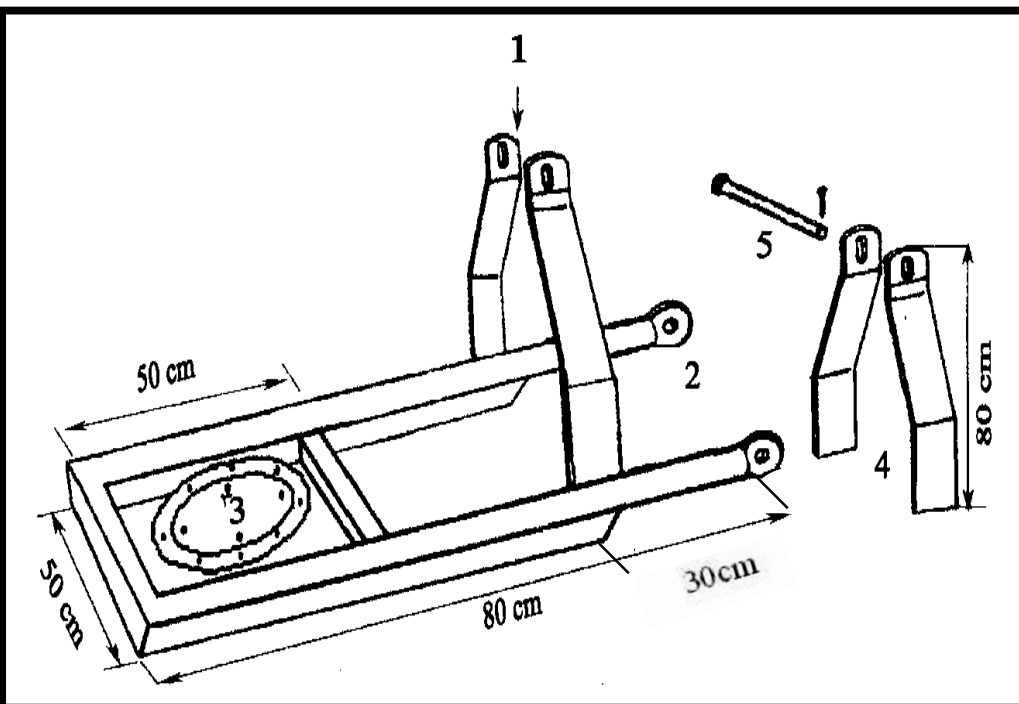

Fig. 4: Turning machine direction and clasp device in compost upright turning machine

1. Height clasp point .

2. Lower clasp point .

3. Splined coupling ( $35 \mathrm{~mm}$ ) .
4. Clasp arms .

5. Pivot pin . 


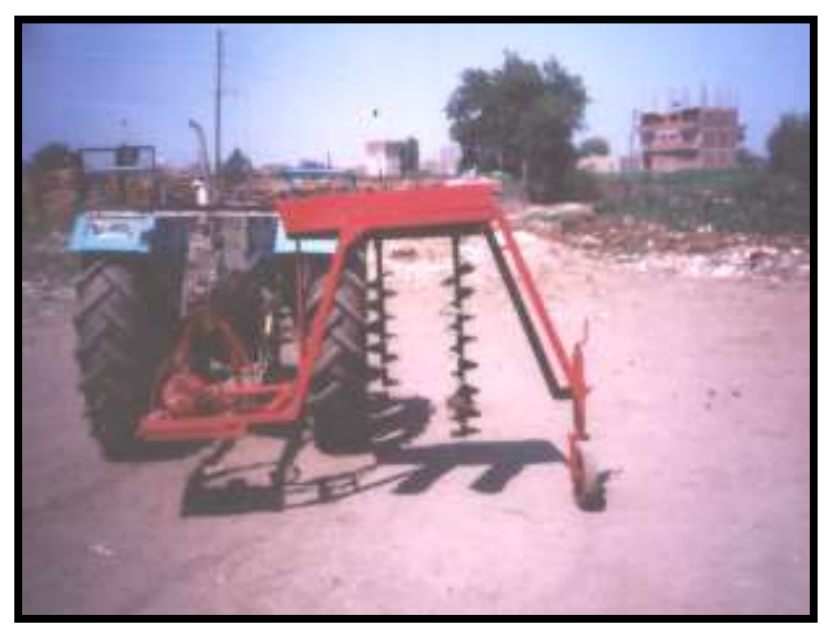

Fig.5: Photograph of upright turning machine .

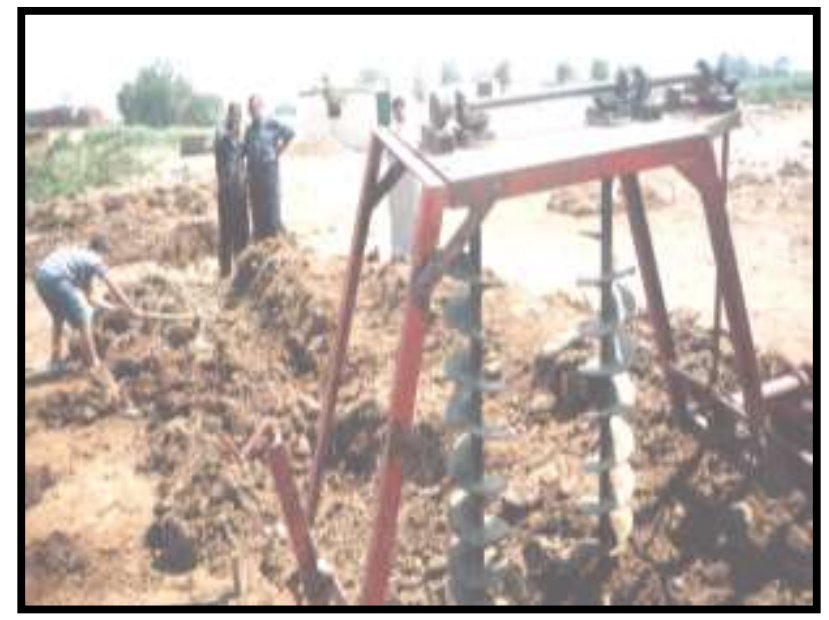

Fig. 6 : Upright turning machine during work on long pile .

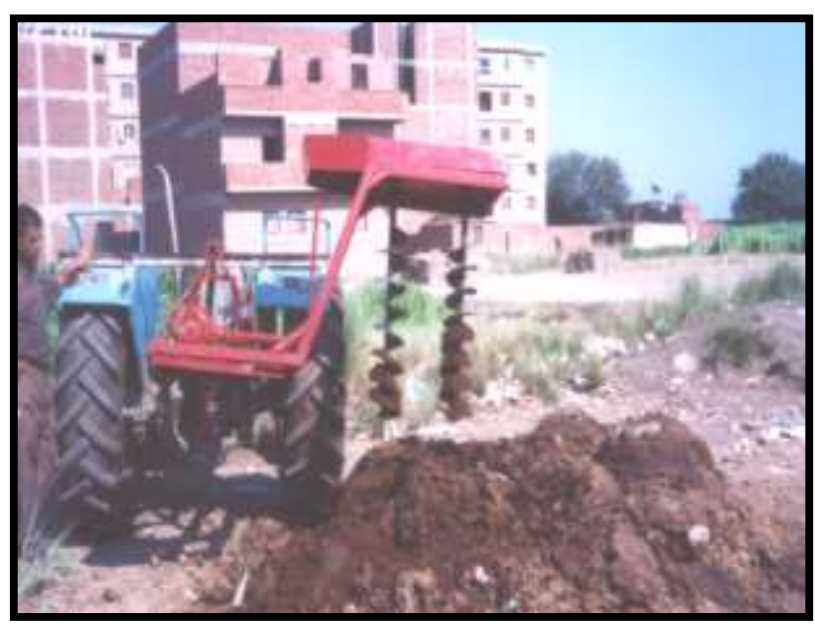

Fig. 7 : Upright turning machine during work on round pile . 


\section{Turning screws :-}

Two turning screws fixed on two Tapered bearings $(35 \mathrm{~mm})$ with transmission system gear. Height of screw is $120 \mathrm{~cm}$ fixed on it are knives of diameter $21 \mathrm{~cm}$, bit height is $11 \mathrm{~cm}$.

\section{Technecal Data :-}

\begin{tabular}{|l|c|c|l|}
\hline \multicolumn{1}{|c|}{ Item } & $\begin{array}{c}\text { During } \\
\text { work }\end{array}$ & $\begin{array}{c}\text { During } \\
\text { Transp } \\
\text { ort }\end{array}$ & Remark \\
\hline mass ( kg ) & 180 & 180 & \\
\hline Width ( cm ) & 210 & 50 & \\
\hline Length (cm ) & 80 & 210 & \\
\hline Turning screw Number & 2 & 2 & $\begin{array}{l}\text { Can be increased in the } \\
\text { prototpe }\end{array}$ \\
\hline Drum Length (cm ) & 110 & 110 & \\
\hline Steps Length ( cm ) & & 11 & \\
\hline Number of knives & 15 & 15 & \\
\hline Drum Width , cm & 20 & 20 & \\
\hline
\end{tabular}

Turning screws speed from 240 to $460 \mathrm{rpm}$, forward speed from 0.3 to $1.1 \mathrm{~m} / \mathrm{sec}$, power source $76 \mathrm{Hp}=(56.3 \mathrm{~kW})$. Transmitted power : from PTO of tractor to turning machine by a flexible joint .

\section{Methods :-}

This investigation was divided into two separate experiments :

\section{The first experiment :-}

The first experiment was carried out to study the effect of the following variables on the performance of the developed compost turning machine .

1.Two pile shapes : long shape and round Shape .

2.Four machine forward speeds :- $0.3,0.6,0.8$ and $1.1 \mathrm{~m} / \mathrm{sec}$. for the long-shape pile and one speed $0.3 \mathrm{~m} / \mathrm{sec}$.for around shape pile.

3.Three rotor speeds :- $(240,350,460)$ rpm for both two pile shapes .

4. Number of compost turnings :- ( $1,2,3$ and 4$)$ Time per month.

To optimize the above mentioned parameters, the following indicators were taken into consideration : 
1.machine capacity : Machine capacity $\left(\mathrm{m}^{3} / \mathrm{sec}\right)$ was determined using the following formula : machine capacity $=\mathrm{A} * \mathrm{~V}$ Where : $A$ : is cross sectional area $\left(\mathrm{m}^{2}\right)$ and $\mathrm{V}:$ is forward speed $(\mathrm{m} / \mathrm{sec})$.

\section{Fuel Consumption :}

Fuel consumption was recorded by accurately measuring the decrease in fuel level in the fuel tank, immediately after executing each operation. Fuel consumption in $\mathrm{L} / \mathrm{m}^{3}$ can be calculated as follows :- Fuel consumption $\left(\mathrm{L} / \mathrm{m}^{3}\right)=$ Consumed fuel $(\mathrm{L} / \mathrm{h}) /$ Machine capacity $\left(\mathrm{m}^{3} / \mathrm{h}\right)$

\section{Power required :}

The required power $(\mathrm{kW})$ was calculated by using The following Formula : P = Wf . CV . $\mathrm{E}_{\text {th }}$. 427 . 1/ . 1 / 136 .( Barger et al .,1963) Where: Wf : fuel consumption $(\mathrm{kg} / \mathrm{s}), \mathrm{CV}$ : calorifice value of fuel (k.cal $/ \mathrm{kg}$ ) . Average C.V. of solar fuel is $10^{4} \mathrm{k}$. cal $/ \mathrm{kg}$. 427 : thermo mechanical equivalent $\left(\mathrm{kg} \mathrm{.m} / \mathrm{k}\right.$. cal), $\mathrm{E}_{\text {th }}:$ Thermal efficiency of the engine (\%),considered to be $30 \%$ for diesel engine .

\section{Energy requirements :}

Calculated by using the following equation :

Energy requirements $\left(\mathrm{kW} \cdot \mathrm{h} / \mathrm{m}^{3}\right)=$ Turning power $(\mathrm{kW}) /$ machine capacity $\mathrm{m}^{3} / \mathrm{h}$.

\section{Turning Cost :-}

Machine Cost was determined by using the following formula :

$\mathrm{C}=\mathrm{P} / \mathrm{h}(1 / \mathrm{a}+1 / 2+\mathrm{t}+\mathrm{r})+\left(0.9 \mathrm{w}^{*} \mathrm{f} * \mathrm{~s}\right)+\mathrm{m} / 144$. ( Awady, 1978 ).

Where : C : hourly cost ; $\mathrm{P}:$ price of the machine $; \mathrm{h}:$ yearly working hours ; a : life expectancy of the machine ; I : interest rate / year ; $\mathrm{t}$ : taxes and overheads ratio; $\mathrm{r}$ : repairs and maintenance rat;w : Power ;f :Specific Fuel consumption.(about 0.41/kW.h); s:Fuel price (L.E/L) ; $\mathrm{m}$ : operator monthly wage ; 0.9 : Factor accounting for ratio of rated power and lubrication ; 144 : The monthly average working hours.

Turning cost can be determined using the following equation :

Turning cost $\left(\mathrm{L} . \mathrm{E} / \mathrm{m}^{3}\right)=$ machine cost $($ L.E $/ \mathrm{h}) /$ machine capacity $\left(\mathrm{m}^{3} / \mathrm{h}\right)$. 


\section{Composting Time :-}

The required time from begining until compost maturity (stability inside pile ) was recorded .

\section{Compost density :-}

Compost density was determined according to the following formula : $\mathrm{P}=\mathrm{M} / \mathrm{V}$

Where : P: Compost density, $\mathrm{g} / \mathrm{cm}^{3}, \mathrm{M}$ :Compost sample mass, $\mathrm{g}$ $\mathrm{V}$ :Compost sample volume, $\mathrm{cm}^{3}$.

\section{The second experiment :-}

The second experiment was conducted to compare between the action of the developed compost turning machine and the manual turning method in respect to final product quality . Final product quality was assessed in terms of the following indicators :

- Percentage of Nitrogen, organic carbon, organic material and Water holding capacity .

\section{RESULTS AND DISCUSSION}

The discussion will cover the results obtained under the following headings :-

\section{Effect of forward speed on machine capacity at different rotor speeds :}

Machine capacity $\left(\mathrm{m}^{3} / \mathrm{h}\right)$ is highly affected by both machine forwared speed, as shown in fig . 10 : Concerning turning long-shape pile results show that increasing machine forwared speed from 0.3 to $1.1 \mathrm{~m} / \mathrm{sec}$. at rotor speeds of ( 240,350 and $460 \mathrm{rpm}$ ) increased machine capacity from 12 to 43 , from 18 to 60 and from 22 to $71.4 \mathrm{~m}^{3} / \mathrm{h}$. during turning long -shape piles ( windrows ).

Experimental work showed that the machine did not work well above , forwared speed of $1.1 \mathrm{~m} / \mathrm{sec}$. due to the high vibration in turning screws.

The increase in machine capacity by increasing forwared speed is attributed to the increase in quantity of turning windrows per unit time .

As to turning round -shape piles, the machine was operated at only forwared speed of $0.3 \mathrm{~m} / \mathrm{sec}$. and different rotor speeds of 240,350 and 
$460 \mathrm{rpm}$. Data show that the machine capacity values were 12,18 and 22 $\mathrm{m}^{3} / \mathrm{h}$. at rotor speeds of 240,350 and $460 \mathrm{rpm}$ respectively .

The reason of turning round shape - piles at one forwared speed : is because the driving around them with high forwared speed has a bad effect on both tractor and machine .

\section{Effect of machine forwared speed on fuel consumption at} different rotor speeds :-

Results in fig. 11: show that the fuel consumption per hour and fuel consumption for preparing one compost cubic metre are greatly affected by both machine forward speed and machine rotor speed . Considering turning long -shape piles, experimental data obtained show that increasing forwared speed from 0.3 to $1.1 \mathrm{~m} / \mathrm{sec}$. at various rotor speeds of 240,350 and $460 \mathrm{rpm}$. increased hourly fuel consumption from 4.8 to 6.4, from 5 to 7 and from 5.4 to $7.4 \mathrm{~L} / \mathrm{h}$, while decreasing fuel consumption for one cubic meter of compost from 0.4 to 0.2 , from 0.33 to 0.17 and from 0.29 to $0.155 \mathrm{~L} / \mathrm{m}^{3}$.

As to turning round - shape pile, results show that the machine was operated at only one forwared speed and three different rotor speeds .

Hourly fuel consumption values were $4.8,5$ and $5.4 \mathrm{~L} / \mathrm{h}$ at rotor speeds of 240,350 and $460 \mathrm{rpm}$ respectively, while fuel consumption values per cubic meter were $0.4,0.33$ and $0.29 \mathrm{~L} / \mathrm{m}^{3}$ under the same previous conditions .

The increase in hourly fuel consumption by increasing forwared speed is attributed to the increase in the amount of turned compost per unit time . The same trend was noticed with rotor speeds, increasing rotor speed increased hourly fuel consumption due to the increase in screw revolutions per unit time, that requires high power resulting in more fuel consumption .

The decrease in fuel consumption per cubic meter by increasing forwared speed is attributed to the increase in machine capacity but only to a certain extent, because fuel consumption per cubic meter slightly increased after the forwared speed of $0.8 \mathrm{~m} / \mathrm{sec}$.

3. Effect of machine forwared speed on power and energy requirements at different rotor speeds :- 
Results in fig.12 show that power and energy requirements are affected by both machine forwared speed and rotor speed with regard to turning long - shape piles obtained show that increasing forwared speed from 0.3 $\mathrm{m} / \mathrm{sec}$. to $1.1 \mathrm{~m} / \mathrm{sec}$ at various rotor speeds of 240,350 and $460 \mathrm{rpm}$, increased power requirements from 60.3 to 90.5 from 70.1 to $90.5 \mathrm{~kW}$ and from 75 to $92.9 \mathrm{~kW}$, while decreased energy requirement from 5 to 3.5 , from 3.5 to 2.5 and from 3.0 to $1.9 \mathrm{~kW} . \mathrm{h} / \mathrm{m}^{3}$.

As to turning round- shape piles, at one forwared speed $0.3 \mathrm{~m} / \mathrm{sec}$ and different rotor speeds of 240,350 and $460 \mathrm{rpm}$. The required power values are $60.3,70.1$ and $75 \mathrm{~kW}$. At The same time, the energy requirement values are $5.0,3.5$ and $3.0 \mathrm{~kW} . \mathrm{h} / \mathrm{m}^{3}$.

The increase in the required power by increasing forwared speed is due to the increase in the quantity of turned compost per unit time. At the same time, required power is also increased by increasing rotor speed and resistance torque that tend to increase fuel consumption as well .

The decrease in the energy requirements by increasing forwared speed is attributed to the high increase in machine capacity . But at the same time, energy requirements increased slightly by increasing forwared speed more than 0.8 up to $1.1 \mathrm{~m} / \mathrm{sec}$.

\section{Effect of machine forwared speed on turning cost at different} rotor speeds :-

Fig.13 shows that both hourly cost and turning cost ( L.E $/ \mathrm{m}^{3}$ ) are highly affected by both machine forwared speed and rotor speed. With regard to turning long - shape piles, data obtained show that increasing forwared speed from $0.3 \mathrm{~m} / \mathrm{sec}$. to $1.1 \mathrm{~m} / \mathrm{sec}$ at various rotor speeds of 240,350 and $460 \mathrm{rpm}$ increased hourly cost from 106.1 to $309,131.1$ to 325 and from 211 to $350 \mathrm{~L} . \mathrm{E} / \mathrm{h}$ while decreasing turning cost from 13 to 11.3 , 12.5 to 8.35 and from 18.3 to $7.1 \mathrm{LE} / \mathrm{m}^{3}$.

As to turning round shape piles, data were recorded at only one forwared speed $0.3 \mathrm{~m} / \mathrm{sec}$. under three rotor speeds ( 240, 350 and $460 \mathrm{rpm}$ ). The hourly cost values were $106.1,131.1$ and $211 \mathrm{~L} . \mathrm{E} / \mathrm{h}$ while turning cost values were $13,12.5$ and $11.3 \mathrm{~L} . \mathrm{E} / \mathrm{m}^{3}$. Hourly cost increased by increasing both forwared and rotor speeds, and resistances requiring more fuel and power and resulting in high cost . while the decrease in turning cost by increasing forwared speed up to $0.8 \mathrm{~m} / \mathrm{sec}$. is attributed to the 
increase in machine capacity . Increasing forwared speed more than 0.8 $\mathrm{m} / \mathrm{sec}$. up to $1.1 \mathrm{~m} / \mathrm{sec}$. tends to increase turning cost .

5. Effect of Number of turns on composting time, moisture content and density of the final product :-

Results in Fig.14 show that composting time, compost dnesity and moisture content are highly affected by number of turns for both long and round- shape piles .

Data show a remarkable decrease in composting time from 26 to 14 weeks and from 27 to 15 weeks for both number of turns per month from 1 to 4 times.

Also, the density decreased from 690 to $560 \mathrm{~kg} / \mathrm{m}^{3}$ and from 690 to 580 $\mathrm{kg} / \mathrm{m}^{3}$ with a decrease in compost moisture content of final product from $55 \%$ to $34 \%$ and from $55 \%$ to $35.3 \%$ under the same previous conditions .

The decrease in composting time, density and moisture content for final product is attributed to the increase in aeration rate and active composting that generates considerable heat, large quantities of carbon dioxide, and water vapor .

6. Effect of turning method on some physical and chemical properties of final product :-

Fig. 15 shows the effect of turning method on some physical and chemical specifications of final product in terms of Nitrogen, organic carbon, organic material and water holding capacity percentage .Relating to nitrogen percentage, results show that nitrogen percentage were 1.31 and $1.03 \%$ in turning long - shape piles using turning machine and manual turning respectively .

Meanwhile Nitrogen percentages were 1.1 and $0.7 \%$ in turning round shape piles under the same previous conditions.

Considering organic carbon, data show that organic carbon percentages were 19.9 and $17.5 \%$ in turning long-shape piles using turning machine and manual methods respectively, while organic carbon percentages were 18.6 and $14 \%$ during turning round -shape piles under the same previous conditions. 


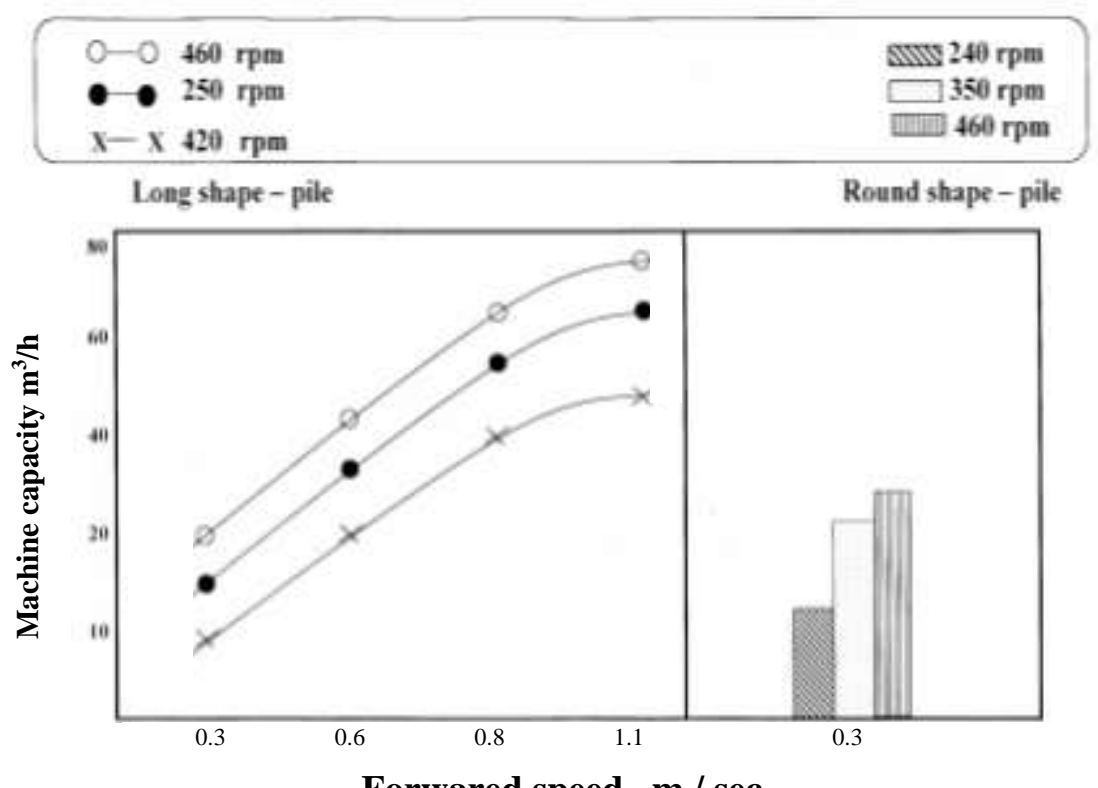

Forwared speed , $\mathbf{m} / \mathrm{sec}$.

Fig.8 : Effect of forwared speed on turning machine capacity at different speeds

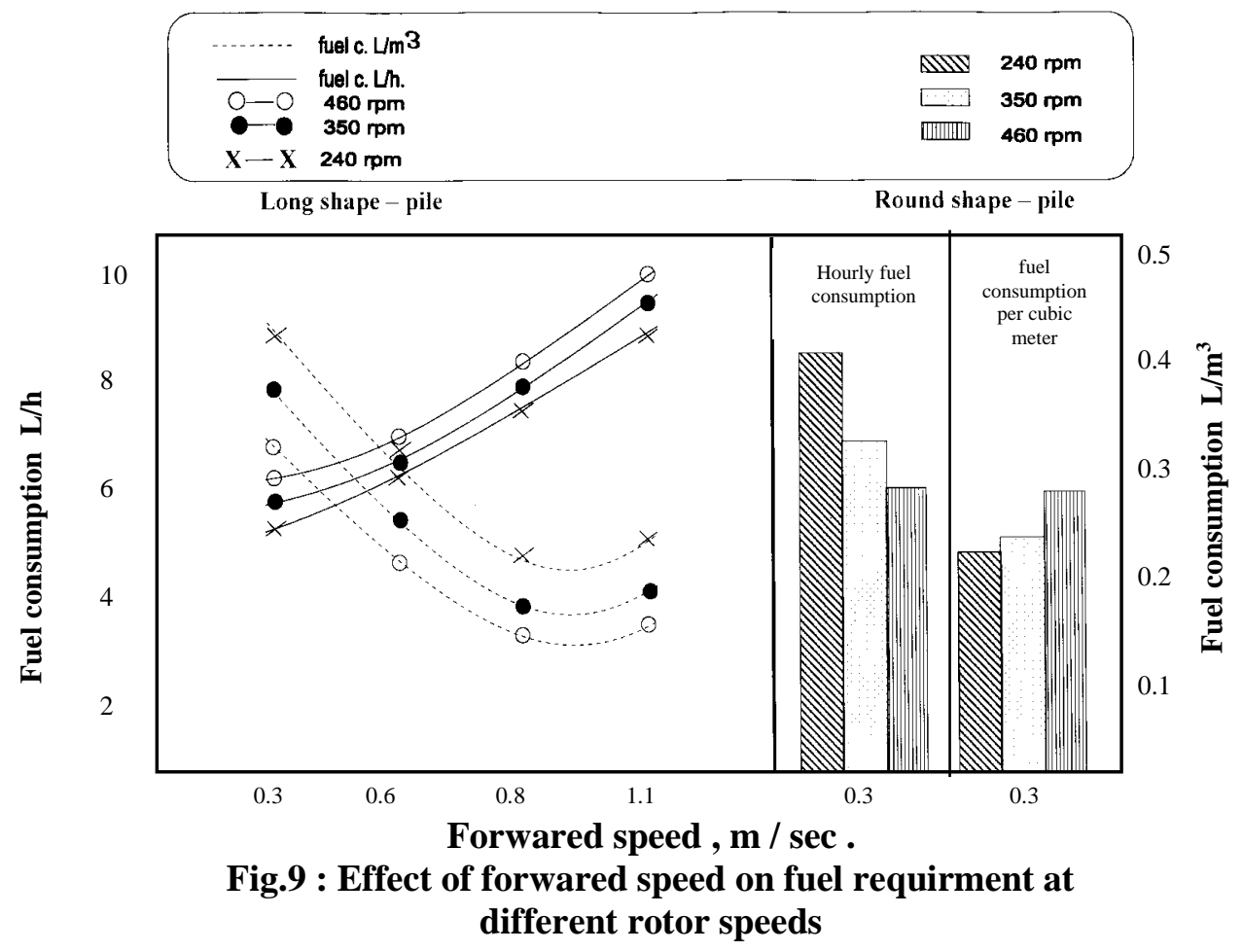

Misr J. Ag. Eng., July 2008 


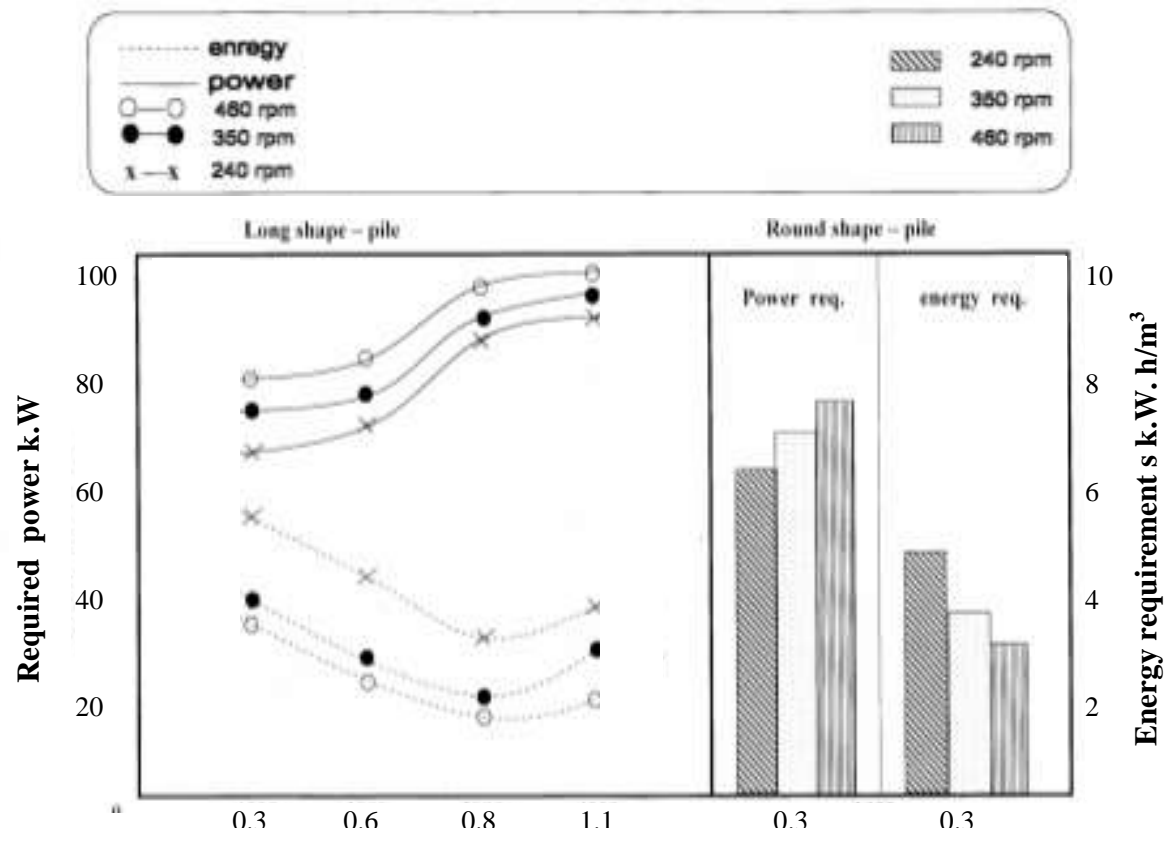

Forwared speed , m / sec .

Fig .10: Effect of machine forwared speed on power and energy requirment at different rotor speeds

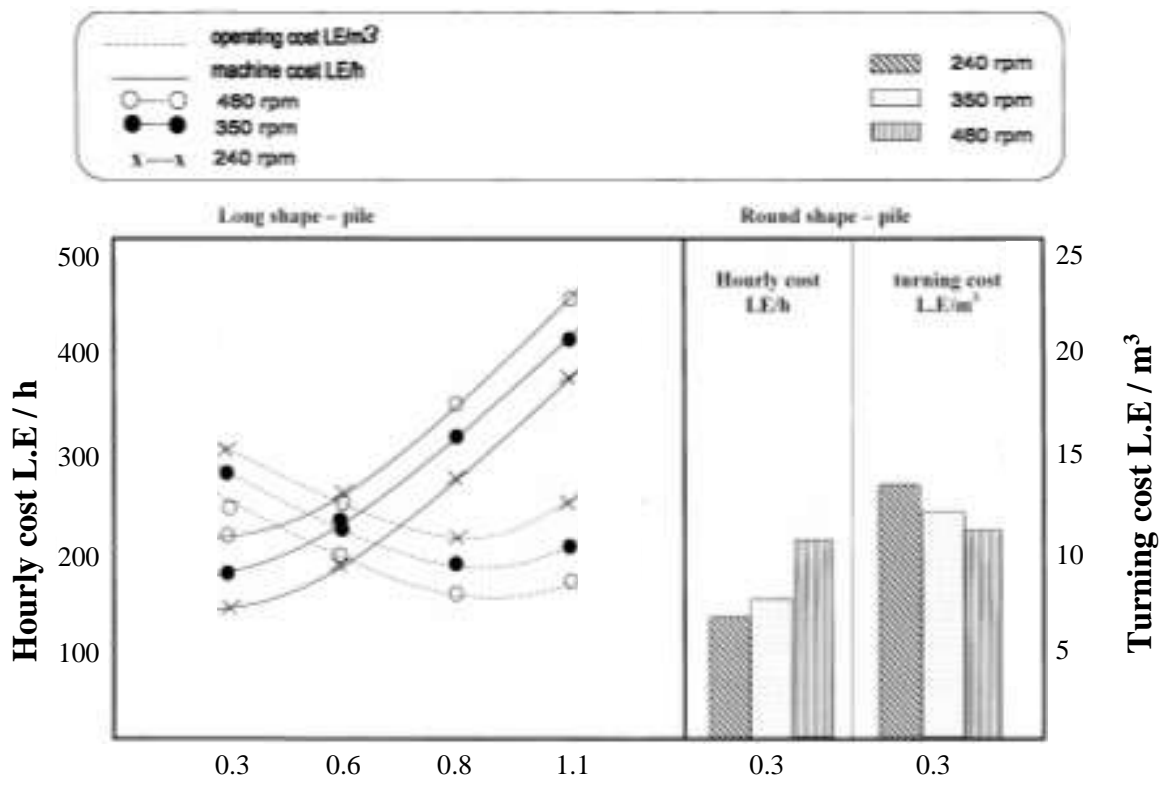

Forwared speed , m / sec .

Fig.11: Effect of machine forwared speed on hourly cost and turning cost . 

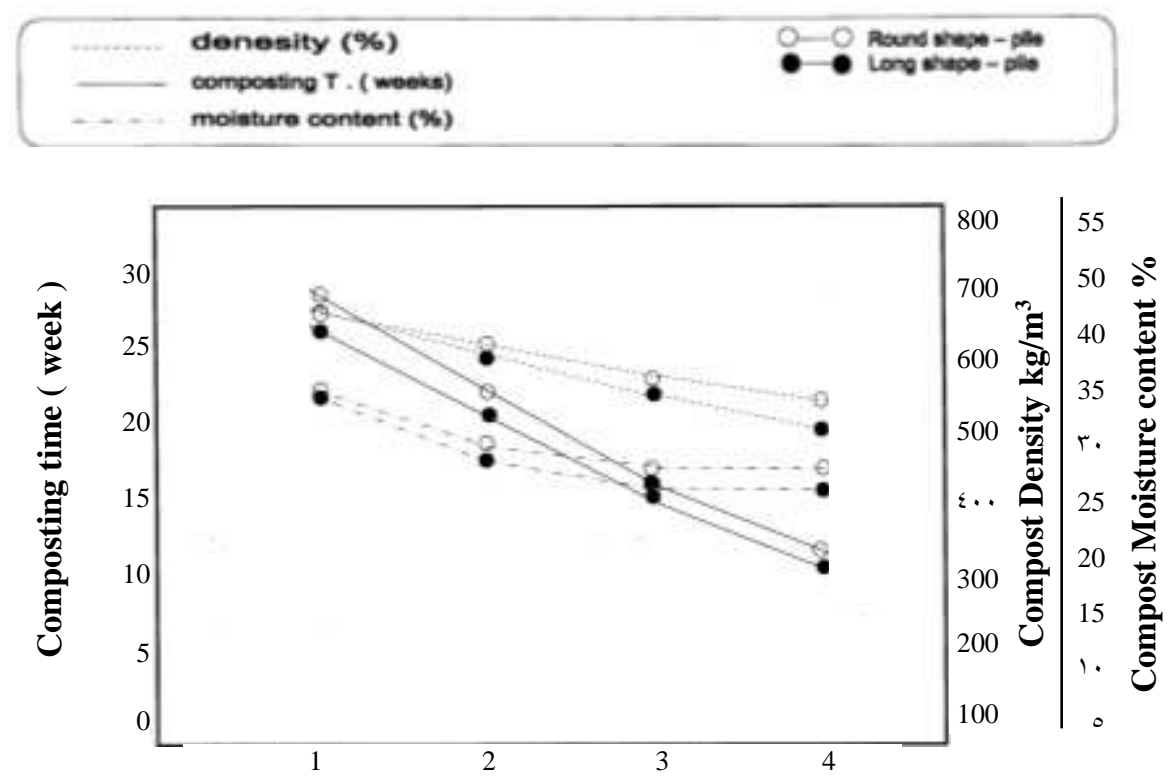

Turning number

Fig.12: Effect of turnng number on composting time, moisture content and density of the final product

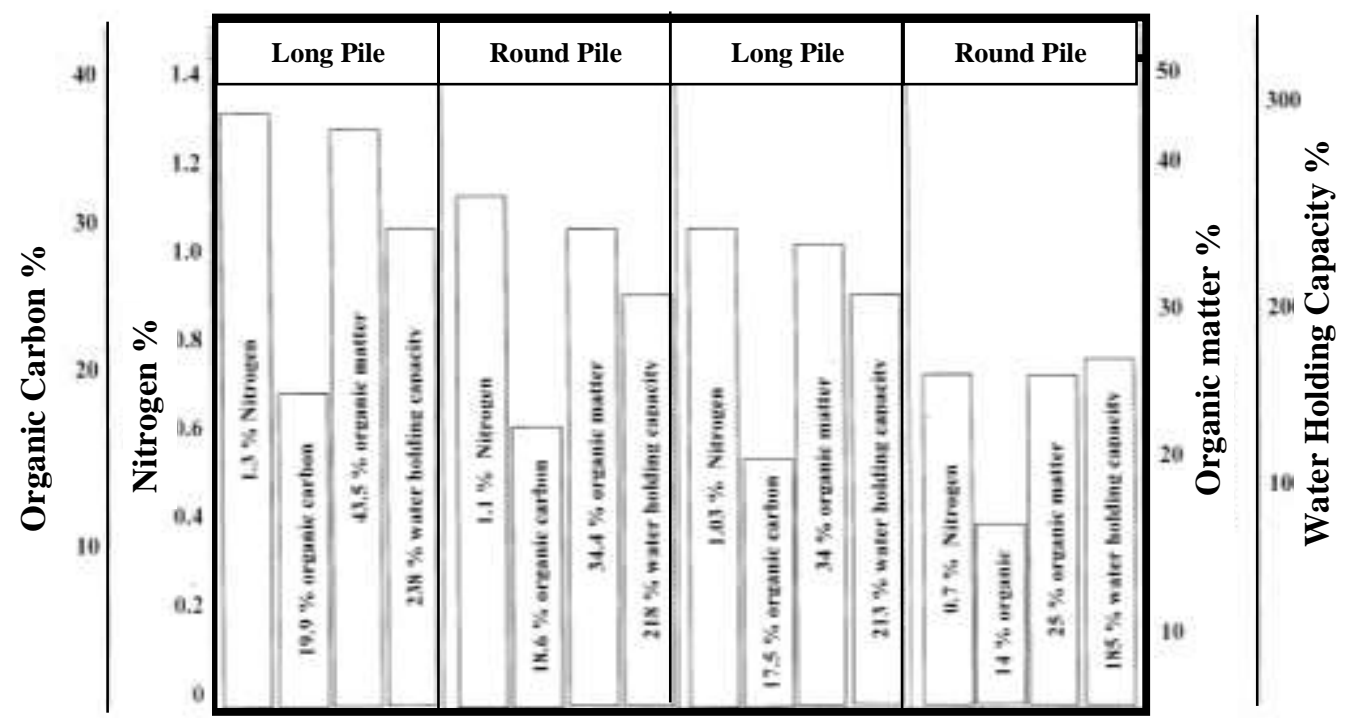

Fig.13: Effect of turning method on some physical and chemical specifications of find product 


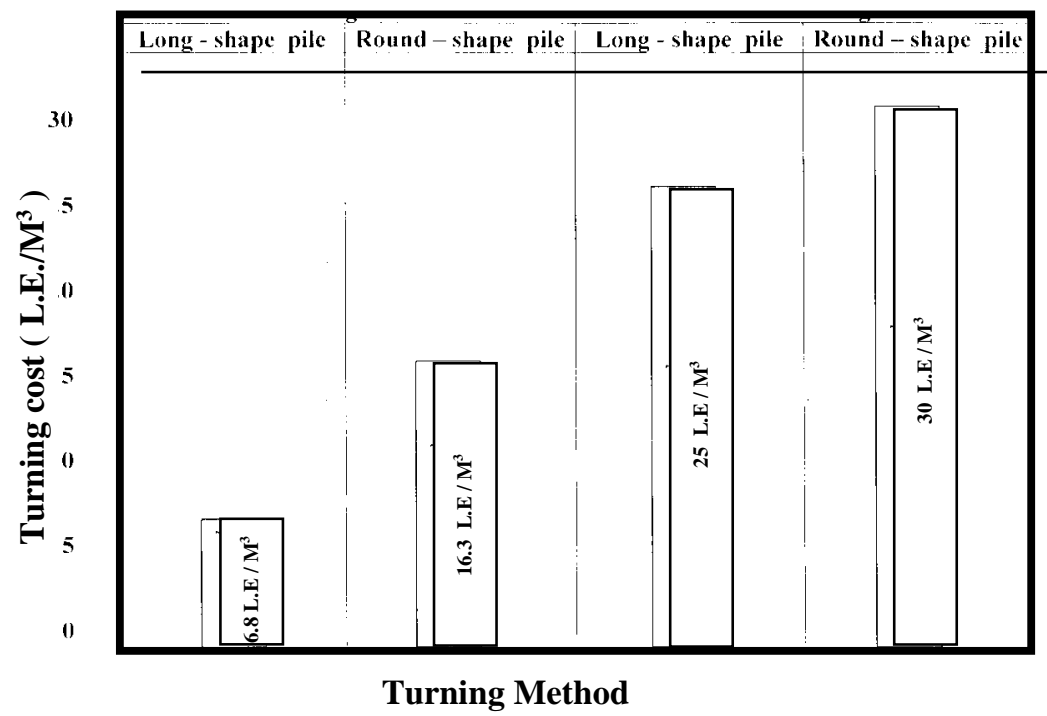

Fig.14: Effect of turning method on turning cost

Concerning organic material, obtained data show that organic material percentage values were 43.5 and $34 \%$ in turning long-shape piles using turning machine and manual turning. Meanwhile these were 34.4 and $25 \%$ in turning round-shape piles under the same previous conditions .

As to water holding capacity, data show that water holding capacity were 238 and $213 \%$ in turning long-shape pile using turning machine and manual turning respectively. Meanwhile these were 218 and $185 \%$ in turning round-shape piles under the same previous conditions .

It is obvious from the above mentioned results that turning compost using the manufactured turning machine improves physical and chemical properties of the final product comparing with the manual method .

\section{Effect of turning method on turning cost :-}

Turning costs were considered the major factor in reducing the price of the final product and principal factor in selecting the composting method . Results in fig . 16 show that turning costs were 6.8 , and $25 \mathrm{~L} . \mathrm{E} / \mathrm{m}^{3}$ during turning long - shape piles by using the designed upright turning machine and manual turning respectively .

Meanwhile turning costs were $16.3,30 \mathrm{~L} . \mathrm{E} / \mathrm{m}^{3}$ in turning round - shape piles under the same previous methods . 
The reduction of turning cost by using the turning machine in both long and round piles was attributed to the higher machine capacity comparing with the manual turning .

\section{CONCLUSION}

From the obtained results it is recommended to use the new design turning machine for small and middle farmers under the following conditions :-

1. Forwared speed of about $0.8 \mathrm{~m} / \mathrm{sec}$. for turning long - shape piles and $0.3 \mathrm{~m} / \mathrm{sec}$. for turning round - shape piles .

2. Rotor speed about $460 \mathrm{rpm}$ for turning both long and round shape piles .

Number of compost turnings per month of (4), for both long and round shape piles .

\section{ACKNOWLEDGMENT}

The researcher acnowledges with appreciation the program partnership in Development Research " SRC - AUC for its support for this study .

\section{REFERENCES}

Abd El - Mottaleb A., F., and Kotob M.,M, ( 2004 ) . Engineering and economical study on compost agitation systems under Egyptian conditions Misr, J.Ag.Eng ., 21 (1) : 33 : 52 .

Abd El - Mottaleb A., F., (2006) Effect of same operating parameters on the performance of compost turning machine, Misr J. Ag .Eng ., 23 (1) : $40-65$.

Rynk , R ., (1992) . On farm composting handbook . NRAES - 54 Ithanca , N.Y, Noth East Regional Agri ., Eng. Services .

Yousef I,S., ( 2001) . A study on mechanization of compost turning and mixing . Misr J.Ag. Eng ., 18 (1) : $45-58$.

Barger E. L. J.L , Edohl ., W. M., Carletor and E.G., Mchibben (1963). Tractors and their power units . $2^{\text {nd }} \mathrm{ed}$., Wiley Sons Inc ., New York U.S.A .

Awady , M., N ., ( 1978) . Tractors and farm machinery ., Txt book ., Col . Ag., Ain Shams U : 146- 167 . ( In Arabic )

Barington ., S.F ., K . ELL - Moueddeb and B. Porter ., (1997) . Improving small scale composting of apple waste Canadian, Agric . Eng ., 39 (1) : 9-16. 
Ministry of Agriculture and land reclamation ( 2001/2002) . Agricultural statice book Agen. Of Agric. For agr. Econ. 87 - 91 . (In Arabic )

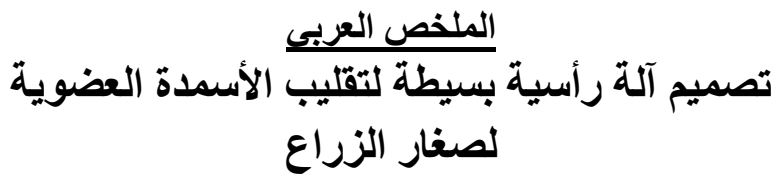

د/ أحمد فؤاد عبد المطلب

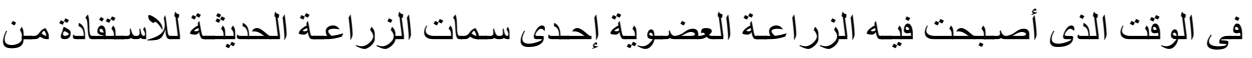

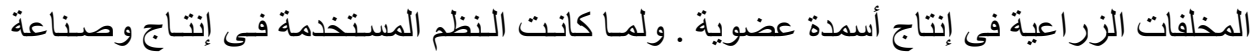

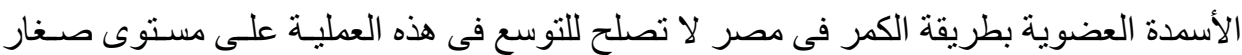

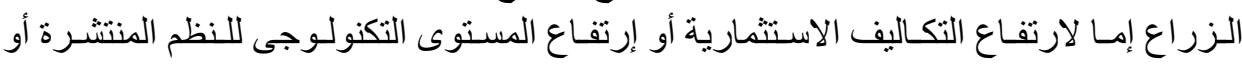

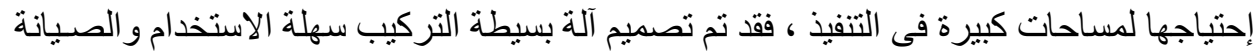

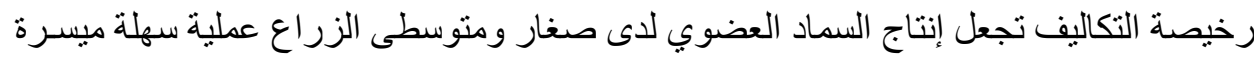

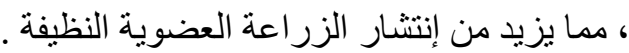

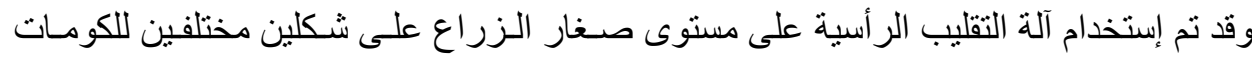

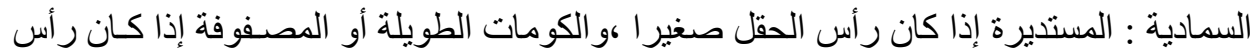

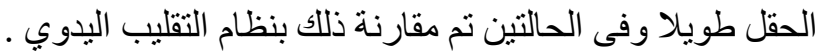

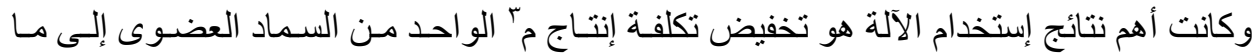

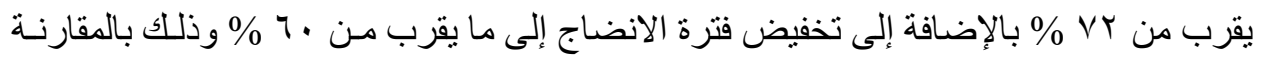

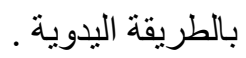

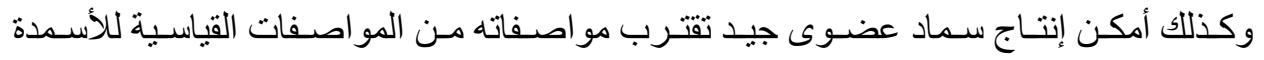

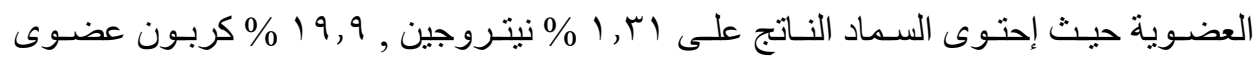

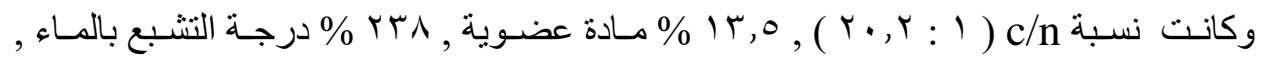

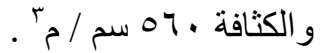

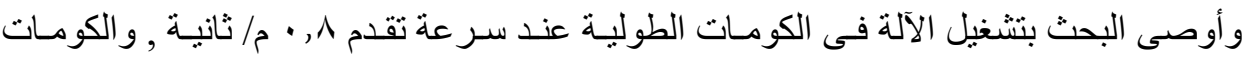

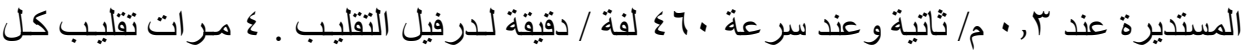

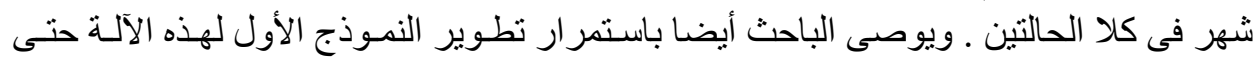

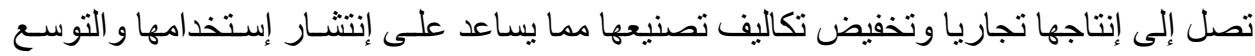

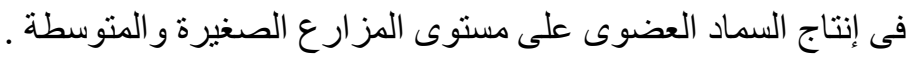

* باحث أول ـ معهد بحوث الهندسة الزر اعية ـ مركز البحوث الزر اعيةـ الدقى - جيزة- مصر 